\title{
PRESTUPOVANIE DIVADLA A POLITIKY. Na príkladoch niekol'kých inscenácií Slovenského národného divadla v rokoch 2013 - 2018
}

\author{
DAGMAR PODMAKOVÁ \\ Ústav divadelnej a filmovej vedy Centra vied o umení Slovenská akadémia vied
}

\begin{abstract}
Abstrakt: Autorka sa zaoberá vybranými inscenáciami Činohry Slovenského národného divadla, dotýkajúcimi sa súčasnej spoločnosti. Pripomína vývin diváka, ktorý neraz nechce už len pasívne prijímat divadelný tvar, ale očakáva od tvorcov aj politický postoj prostredníctvom ich umeleckej tvorby. Na to môžu využit známe či menej známe staršie dramatické texty alebo súčasné hry, ktoré pracujú s aktuálnymi faktami a s vlastnými poznatkami, ako bol napr. Karpatský thriller (2013). Alebo môžu pripravit vlastné interaktívne autorské projekty, ktoré tiež vychádzajú z dokumentačného materiálu, no ich ciel'om je popri všeobecnej informatívnosti získat spätnú väzbu od prijímatel’a - diváka. Takou inscenáciou je Natálka (2016). Nebola len skúškou tvorcov toho, ako sa zhostit chúlostivej témy, ale aj testom toho, do akej miery je spoločnost’ schopná odčítat' metaforu a nehl'adat' v nej za každú cenu nepriatel'a. Najosvedčenejším typom predlohy na uplatnenie politika v divadle je antická dráma. Sofoklova Antigona (2018) citlivým skrátením, vstupom súčasnej pôvodnej hudby mladej generácie a zaktuálnením niektorých obrazov je najnovším príkladom politického postoja tvorcov.

Kl'účové slová: Činohra Slovenského národného divadla, Eugen Gindl, Karpatský thriller, Matúš Bachynec, Miriam Kičiňová, Natálka, Sofokles, Antigona, politikum divadla
\end{abstract}

V súčasnosti sa čoraz viac dostáva do popredia otázka postupných zmien pri vzniku a vnímaní divadelnej inscenácie. Storočia sme boli presvedčení o tom, že divadlo nemá zmysel bez živého diváka v tradičnej sále, interiéroch či exteriéroch rôznych site specific prostredí. Ked’ pre prísne hygienické opatrenia počas pandémie Covid-19 európske divadlá prestali hrat' ${ }^{1}$, množstvo divákov si za niekol'ko týždňov zvyklo sledovat’ záznamy starších inscenácií z pohodlia domovov. Divadlá na vyhradený čas sprístupňovali svoju tvorbu, využívajúc vlastné internetové kanály alebo verejne dostupnú siet’ YouTube, kde zostali mnohé záznamy podnes. Rozšírili sa aj streamované programy. Kým divadelné produkcie klasických divadiel pokryli celú škálu druhov a žánrov, menšie divadelné skupiny či jednotlivci sprostredkúvali cez streamingové prenosy l'ahšiu, skôr improvizačnú formu.

Zatial' nie je k dispozícii sociologický prieskum toho, aký žáner diváci uprednostňujú pri sledovaní live prenosov divadelných produkcií či ich záznamov. Na Slovensku sa po roku 1989 neuskutočnil žiadny reprezentatívny sociologický výskum návštevníkov divadla. ${ }^{2}$ Nevieme teda, ako sa zmenilo ich správanie, čo očakávajú od

\footnotetext{
${ }^{1} \mathrm{~S}$ takouto situáciou sme sa na Slovensku stretli po prvý raz. Slovenské národné divadlo hralo aj počas 2. svetovej vojny, dokonca aj po americkom bombardovaní Bratislavy v júni 1944, ked’ popri rafinérii Apollo a iných objektoch bola poškodená aj ned’aleká budova Slovenského národného múzea.

${ }^{2}$ Národné osvetové centrum na začiatku tohto storočia skúmalo záujem o divadlo na reprezentatívnej vzorke obyvatel'stva, čím zachytili aj tzv. ne-divákov. Viac BLAHO, V. Ako je s naším divadlom? K výskumu vztahu slovenskej populácie k divadlu. In Slovenské divadlo, 2004, roč. 52, č. 4. s. 313 - 332.
} 
divadelného predstavenia všeobecne, či od konkrétneho súboru. A naopak, akého diváka si divadlo predstavuje. ${ }^{3}$

V súvislosti s činoherným divadlom sme za posledné desatročia aj u nás postrehli istú zmenu diváckej obce od pasívneho prijímatel’a k emancipovanému divákovi. Sledujeme postupný odklon od primárneho umeleckého zážitku na divadelnom predstavení s ciel'om vyvolat' u diváka záujem premýšlat’ o nastolenej téme a jej spracovaní, či dokonca ho interaktívne zapojit’ do deja. Dokumentárne divadlo, ktorého účelom je vyjadrit’ sa rôznymi formami k minulosti a súčasnosti, tento vývin ešte urýchl'uje. Záleží na tom, čo si divadelní tvorcovia vyberú z možných podkladov. Na to, aby zaujali postoj k spoločenskému dianiu v konkrétnej krajine či k téme presahujúcej hranice, nepotrebujú vychádzat iba z reálií, môžu využit aj všeobecne známe dramatické texty. Závisí len od nich, či zvolené umelecké prostriedky spoločenských faktov a súvislostí konkrétnej doby smerujú k politickému, alebo len politizujúcemu divadlu. Svoj program zrkadla spoločnosti môžu realizovat’ prostredníctvom klasických svetových i domácich dramatických textov (čoho svedkami sme boli na Slovensku v čase normalizačného obdobia v rokoch 1970 - 1989) alebo novými hrami/scenármi, ktoré sprítomňujú mnohé historické skutočnosti, prevažne politického charakteru (Slovenská republika 1939 - 1945, holokaust, pät’desiate roky - vrátane justičných vrážd, okupácia Československa 1968 a. i.).

Ďalšou možnostou je reflexia prítomnosti. Tá ponúka množstvo námetov. Mnohé sa týkajú viacerých krajín, nielen európskych (napríklad korupčné škandály nadnárodných spoločností, migrácia atd’.), iné sú pevne zakotvené v domácom prostredí (tzv. malé korupcie či konanie niektorých predstavitel'ov tej-ktorej politickej strany a. i.). Tvorcovia sa slobodne rozhodujú pre žáner a jeho formu. V menšom divadle/ súbore s istým okruhom divákov sa skôr dohodnú na zmene dramaturgického titulu, tvaru a výpovedi ${ }^{4}$ než v tzv. kamennom, ktoré spravidla hráva na väčších scénach a musí plnit’ aj úlohy dané osobitným zákonom (Slovenské národné divadlo).

Čast' diváckej obce neraz očakáva, že divadlo bude prostredníctvom umeleckého diela prezentovat' nepriamo aj politický názor (pričom vo vel'kom kolektíve môže byt’ rôznorodý). Javisko však nie je politická tribúna, predpokladá zdivadelnenie faktov a súvislostí. Pri autorských textoch často vychádza z nazbieraného materiálu od respondentov (verbatim, oral history), no ich výpoved’ upravuje, dopíňa d’alšími, aj protirečivými informáciami a umeleckou fikciou. Niekedy stačí len skrátit’ známy text a pracovat' viac s metaforou. Osobitú úlohu hrá aj herectvo a kontakt s divákom, ktorý závisí od vel'kosti hracieho priestoru a jeho usporiadania. Ak sa hra privel'mi dotýka konkrétnych udalostí, ako aj ich zovšeobecnenia, nemožno obíst’ ani vhodnost' načasovania uvedenia.

V novembri 2016 publikovalo NOC záverečnú správu z výskumu Kontinuálny sociologický výskum spotreby kultúry v Slovenskej republike, ktorý s divadlom súvisí len čiastočne. Pozri https://www.nocka.sk/ wp-content/uploads/2018/03/zaverecna-sprava-z-vyskumu-spotreby-kultury-2016_final.pdf. [online]. [cit. 21. 4. 2020]. Kvantitatívnemu prieskumu skutočných návštevníkov sa nevenuje pozornosṫ.

${ }^{3} \mathrm{~V}$ Čechách a v niektorých d’alších krajinách sa zaoberali prieskumom práce s publikom viacerých kultúrnych organizácií. Pozri napr. RE: Publikum. Př́ležitosti a rizika práce s publikem. Praha : Institut umění, 2016. Online vydanie dostupné na internete: https:/www.kreativnievropa.cz/wp-content/uploads/2018/02/2-republikum-2016_publikace_190x230.pdf.

${ }^{4}$ Ide najmä o menšie divadelné zoskupenia s výraznou autorskou osobnostou, napríklad GUnaGU, Divadlo SkRAT, ale aj Radošinské naivné divadlo. 
Na zvolených inscenáciách Činohry SND si všimnime rozdielny prístup tvorcov $\mathrm{k}$ divadelnému obrazu vážnych tém súvisiacich s politikom súčasnej (rozumej vtedajšej, resp. dnešnej) spoločnosti. Prvou je Karpatský thriller (2013), v súvislosti s ním nepriamo aj Rivers of Babylon (2016, obe v Štúdiu SND), druhou projekt Natálka (2016), prioritne určený pre školy, ale odohraný aj v domácom priestore Modrého salóna, a poslednou, ešte živou, Sofoklova Antigona (2018) na vel'kej scéne činohry.

\section{Slová a obraz na javisku, ticho vo verejnosti}

Karpatský thriller ${ }^{5}$ mal premiéru 13. novembra 2013 v Štúdiu SND. Symbolicky pred 26. výročím Nežnej revolúcie sa na javisku objavila hra, v ktorej sa nahlas hovorilo o spletitých cestách korupčných praktík a klientelizmu. V texte sa spomína známa firma len iniciálou $S$, ale v inscenácii zaznie aj celý názov spoločnosti Siemens, ktorá mala na Slovensku monopol na štátne zákazky dodávok zdravotníckej techniky a i. Čierne fondy a úplatkárstvo Siemensu vyšetrovali v tom čase už vo viacerých európskych krajinách aj v USA. ${ }^{6}$

Divadelná prvotina investigatívneho publicistu a televízneho scenáristu Eugena Gindla vznikla cielene, hoci spočiatku neplánovane. Autor sa ako redaktor mesačníka OS (Občianska spoločnost') dostal ešte v máji 1998 k podkladom, ktoré potvrdzovali, že na Slovensku sa v druhej polovici devätdesiatych rokov nakupovala v rámci verejného obstarávania moderná zdravotná technika (magnetická rezonancia, angiografy a i.) od Siemensu ovel'a drahšie než ponúkali druhí dodávatelia, a to aj v porovnaní s inými štátmi. Od dvoch insiderov získal Gindl ešte d’alšie, podrobnejšie informácie. Materiál ponúkol súkromnej televízii a viacerým printovým vydavatel’om, ktorí sa pravdepodobne zlakli poprepletaných súvislostí a konkrétnych mien najvplyvnejších lobistov, medzi ktorými boli aj poslanci slovenského parlamentu. Ako nepriama odpoved' sa v inzercii oslovenej televízie objavila decentná reklama na uvedenú firmu. Ked' mesačník OS v dvoch článkoch odhalil viaceré podrobnosti, nič sa nedialo, nikto nepodal na redakciu žalobu. ${ }^{7}$ Prekvapila pasivita verejnosti, ale aj vládnych činitel’ov či poslancov. ${ }^{8}$ Slovenská spoločnost’ bola unavená zo všeobecnej malej korupcie, tej väčšej - nadnárodnej či na úrovni „finančných žralokov“ - nerozumela, navyše OS nemal vysoký náklad a čítala ho len čast’ politicko-spoločenského spektra obyvatel'stva.

Ked' v roku 2010 vypísala Činohra SND sútaž o nové dramatické texty, Eugen Gindl na podnet dramaturga Martina Porubjaka poslal hru s týmto „starým“ námetom. Po spolupráci s dvomi dramaturgmi (M. Porubjak, Peter Kováč) vznikol text,

\footnotetext{
${ }^{5}$ Premiéra 13. 11. 2013, derniéra 25. 2. 2017, spolu odohrali 69 predstavení. Réžia Roman Polák, scéna Andrej Ďurík, kostýmy Katarína Hollá, hudba Vladislav Šarišský.

${ }^{6} \mathrm{Na}$ Slovensku napriek podozreniu nepadlo ani jedno obvinenie, hoci napríklad v Bratislave získala ešte v korunách miliardové kontrakty pri bratislavskom mestskom osvetlení. V najväčšom korupčnom škandále $\mathrm{v}$ dejinách nemeckého hospodárstva sa spoločnost’ Siemens negatívne zviditelnila prostredníctvom čiernych fondov, ktoré sa z vel'kej časti použili na podplácanie pri získavaní zákaziek v zahraničí. Preto ich dozorná rada pristúpila v roku 2007 na radikálnu prestavbu koncernu.

${ }^{7}$ Viac GINDL, E. - PORUBJAK, M. Sme všetci len herci? In Eugen Gindl: Karpatský thriller [Bulletin k inscenácii]. Bratislava : Slovenské národné divadlo, 2013, s. 10. Divadlo sa rozhodlo pre netradičný bulletin vo formáte a s hlavičkou denníka Sme.

${ }^{8}$ V septembri 1998 sa uskutočnili vol'by do Národnej rady SR a do orgánov samospráv obcí, zmenil sa premiér i zloženie parlamentu.
} 
ktorý má niekol'ko rovín a ktorý o tri neskôr inscenoval Roman Polák. Základom je príbeh bývalej redaktorky Zuny (Zuzana Fialová), ktorá už rezignovala na zviditel'ňovanie káuz a založila si reklamnú agentúru. Napriek tomu jej Harlekýn (tu ako insider firmy S, jedna z podôb Deus ex machina) ponúkne materiál o rozsiahlej korupcii nadnárodnej spoločnosti $S$, vedúcej až na najvyššie miesta. Zuna váha, témou sa rozhodne zaoberat' až vtedy, ked' jej blízka priatel'ka Nad’a/Líštička (Petra Vajdová) potrebuje absolvovat t’ažko dostupné vyšetrenie magnetickou rezonanciou, na ktoré sa čaká niekolkko mesiacov.

Autor pri písaní vychádzal z vlastných i všeobecných skúseností. Zunin scenár natočia, ale televízia Kométa reláciu neodvysiela a v časopise, ktorý sa zaoberá zdravím, jej článok odmietnu uverejnit'. Fonundcu (Dušan Jamrich), šéf firmy $S$, navrhne pre jej nevel'mi úspešnú agentúru výhodnú zákazku, ale Zuna odmieta. Nepodl’ahne zastrašovaniam ani vtedy, ked’ si „kúpia“ jej najbližšieho spolupracovníka, režiséra reklám Džonyho (Jozef Vajda/Lubomír Paulovič), či ked’ ju citovo vydierajú pre lesbický vzt’ah s Nad’ou. V priebehu deja vychádzajú na povrch d’alšie skutočnosti: Nadina minulost' prostitútky na Balkáne, kam sa dala zlákat’ vidinou zárobku, zabitie klienta v sebaobrane v Holandsku, dvojitá hra Harlekýna, spolupráca firmy S aj s opozíciou prostredníctvom financovania predvolebnej kampane, opísanie rôznych postupov pri úplatkoch, vyhrážaní sa a i. Všetko do seba zapadá a odzrkadluje realitu tých dní.

Druhá, sčasti mýtická rovina, sa prejavuje prevtelením bytosti Deus ex machina do viacerých postáv (Daniel Fischer). V podobe Anjela sa znesie na Slovensko, neskôr v iných postavách osvetl'uje príbeh i zasahuje doň. Hrobár (Leopold Haverl), vypožičaný z Hamleta ${ }^{9}$, na mafiánskom cintoríne odkrýva i vtipne komentuje praktiky odstraňovania nepohodlných l'udí v devätdesiatych rokoch. Zverejnený text končí vystúpením Harlekýna z postavy a navrátením sa do Deus ex machina. Už ako Zeus vyberie z tašky Harlekýnovu hlavu a podá ju Hrobárovi, ktorý práve pochováva telo bez hlavy, a za flašu borovičky ich spoločne vloží do hrobu. ${ }^{10}$

Režisér Roman Polák využil Brechtovo odcudzenie i v postave Uny (Marta Matová), ktorá dej komentuje i posúva, slovne stále pripomínajúc tie „hroznédevät’desiate roky“. Aj bývalý Nadin pasák, dnes zemplínsky mafián Braňo Bubák (Milan Ondrík), sa tu zjavuje ako doktor Bubo, požadujúc od Nade zastrelenie Harlekýna, či ako karnevalový čert st̉aby opozitum bieleho Anjela. Obdobne sú písané aj niektoré repliky/ dialógy, v ktorých herci vystupujú zo svojich postáv. Príkladom je dialóg Anjela so Zunou (tvorcovia ho doplnili do textu a situovali pred záverečnú scénu s Hrobárom). Znechutená Zuna po posledných Fonundcových slovách „Ja sa vrátim“ hladá východisko zo situácie, v ktorej sa ocitla, ked’že autor nenapísal koniec tejto postave. Deus ex machina na kolobežke s krídlami Anjela jej predostiera katastrofické riešenia, napr. alkoholizmus, strata všetkých priatel'ov z jej frustrácie z korupcie, skončenie na psychiatrii, ako aj vstup do politiky.

Navonok zložité rozprávanie je na javisku jasné a nekomplikované. Tvorcovia ho ozvláštnili rýchlymi, priam filmovými strihmi, miešaním reality, fikcie, frašky, symbolizmu tak, že inscenácia pôsobila pútavo, dynamicky a miestami až agresívne. Postava šéfa firmy $S$ na Slovensku vyznela ako príklad neobmedzenej vel'kosti, drzosti,

\footnotetext{
${ }^{9}$ Podla bulletinu.

${ }^{10}$ Pozri koniec hry. In Eugen Gindl: Karpatský thriller [Bulletin k inscenácii], s. 19.
} 


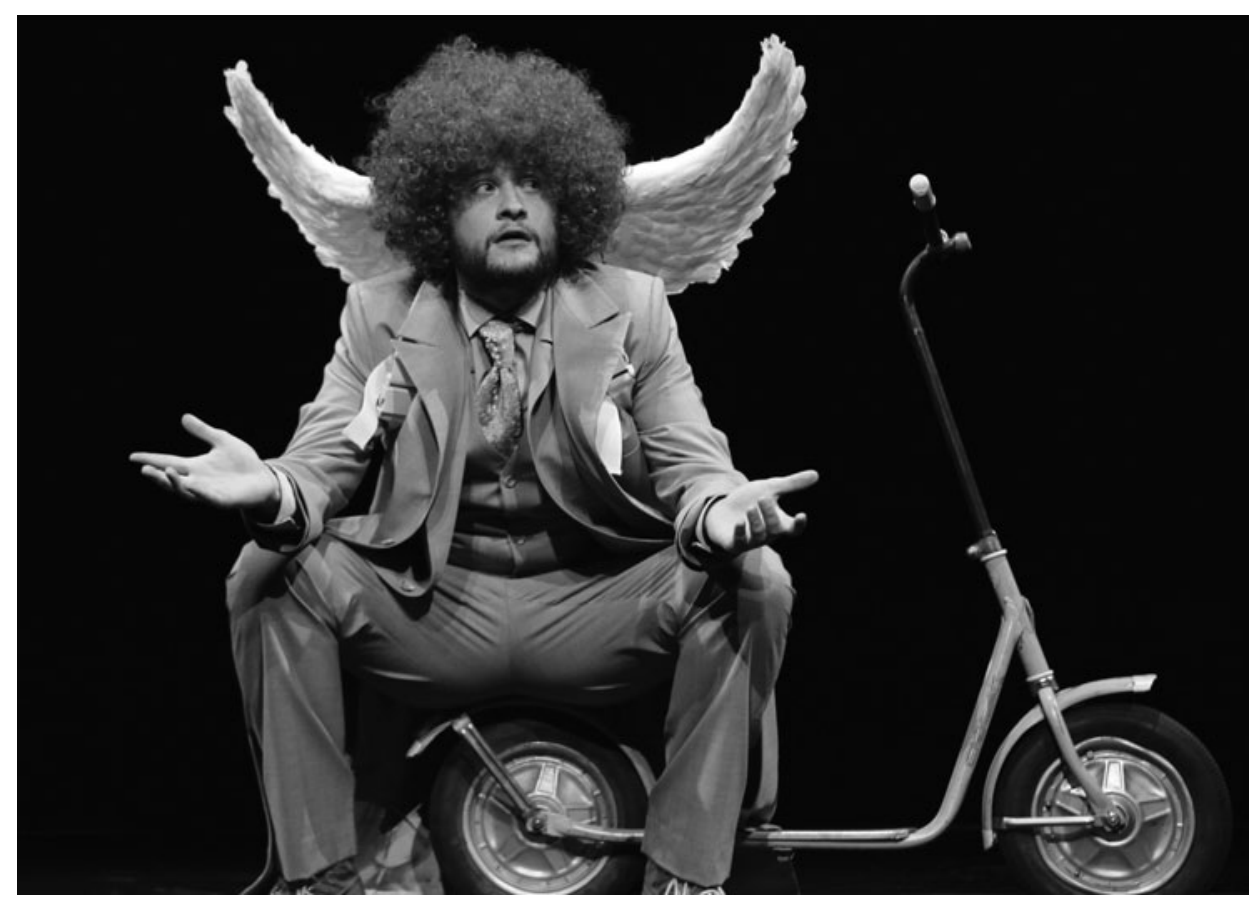

Eugen Gindl: Karpatský thriller. Činohra Slovenského národného divadla, premiéra 13. 11. 2013. Réžia Roman Polák. Daniel Fischer (Deus ex machina a jeho reinkarnácie). Foto archív SND. Snímka Ctibor Bachratý.

samolúbosti aj v tom, ako otvorene hovorí o prepracovanom systéme podplácania lekárov, riaditel’ov, nákupcov i d’alších ludí doma a v iných krajinách. ${ }^{11}$

Divadelná podoba tejto spoločensky odvážnej hry sa prejavila v rôznorodosti štýlov herectva (môže byt' poňaté ako obraz vtedajšej „novej“ spoločnosti), ako aj v kostýmovaní postáv. Katarína Hollá popri dobovom odeve využila štylizáciu, skratku (biele masky na plese elít, kostry širokých sukní), Hrobár ako metafora smrtky si na javisku brúsi svoj pracovný nástroj rýl', atd’. Realita devät’desiatych rokov sa na scéne miestami pretavila do tragikomédie, ale v slovenskej spoločnosti 21. storočia mimo divadla boli mnohé z jej praktík stále živé. Teatralizácia dokumentárnych materiálov ponúkla politické divadlo v krajine, ktorá nebola zvyknutá takto priamo a zároveň s úškl’abkom hovorit’ o korupcii politikov či novinárov. Vzdialene pripomenula alegorické obrazy Polákovej inscenácie Nebo, peklo, Kocúrkovo v Činohre SND z roku 1995. ${ }^{12}$

${ }^{11}$ Ako sa ukazuje, problém korupcie pretrváva aj dnes, menia sa len komodity, ale divadlá sa takýmto témam nevenujú.

${ }^{12}$ Roman Polák pri inscenovaní tejto hry Karola Horáka, ktorá vychádza z viacerých rukopisov Jonáša Záborského (Vstúpenie Krista do raja, Faustiáda a iné texty), vytvoril obdobný obraz Slovákov, avšak zložito schovaný pod viacero vrstiev metafor. 


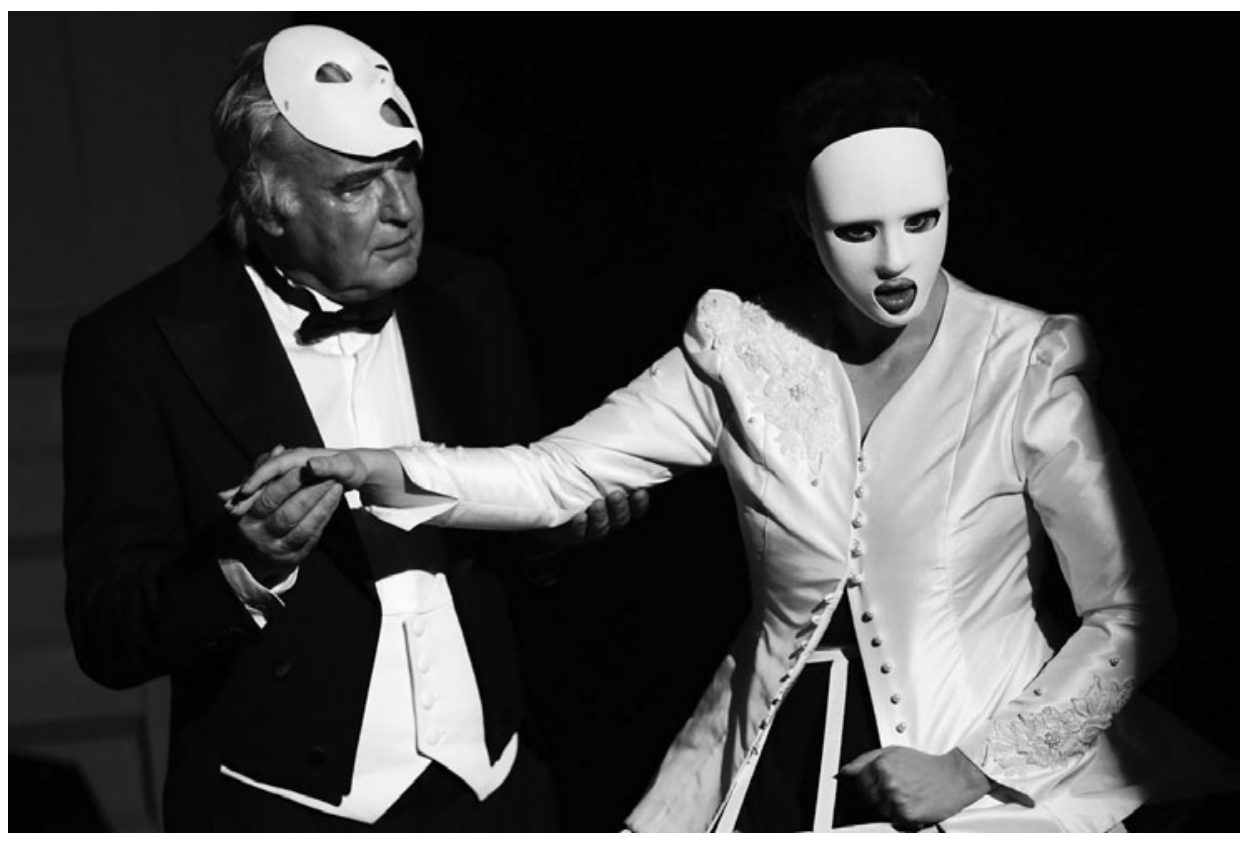

Eugen Gindl: Karpatský thriller. Činohra Slovenského národného divadla, premiéra 13. 11. 2013. Réžia Roman Polák. Dušan Jamrich (Fonundcu), Zuzana Fialová (Zuna). Foto archív SND Snímka Ctibor Bachratý.

Záverečný výstup už pri rozsvietených svetlách v hladisku je logickým dôvetkom k výpovedi tvorcov prostredníctvom postáv Gindlovej hry, na ktorý ju naviedol Deus ex machina. Ironicky a zároveň pravdivo vyznieva prispôsobená modlitba, v ktorej Zuzana Fialová a predčítava slová a ostatné postavy s maskami na tvári ich opakujú, vyzývajúc finančné skupiny kradnút' s mierou a odpustit’ obyčajným l'ud’om, že aj oni tu chcú žiť. Výstup má jasné spoločenské posolstvo. Prosia občanov, aby múdro volili poslancov, prezidentov, lebo ak sa za desat' rokov nič nezmení, tak sa Slovensko stane krajinou mutantov predchádzajúcich a súčasných politikov. Prosbu anonymného davu bez tvárí sčasti oslabili vložené hrozby o možnom radikalizme, uchopení spravodlivosti do vlastných rúk prostredníctvom vzbury, zabíjania, nastolenia chaosu, krutosti a strachu, ktoré už kolektívne recitujú sami, bez predčítania.

Touto predikciou budúcnosti sa tvorcovia ocitli na rozhraní univerzálneho divadelného modelu obrazu politika súčasnosti a zovšeobecnenia témy korupcie za každej politickej moci (aj na Slovensku). Programový bulletin s fiktívnymi cenzúrnymi zásahmi zahŕňa mená tvorcov a postáv, texty hry, rozhovor s autorom a článok druhého dramaturga P. Kováča Korupčná dráma - nový žáner demokracie?, no inak obsahom, členením rubrík a grafikou kopíruje formát denníka Sme. Všetky príspevky sú pôvodné, miestami písané s plnou vážnost’ou žurnalistiky, aby vzápätí bolo jasné, že ide o iróniu, frašku či smiech cez slzy.

Inscenátori sa zámerne odklonili od tradičnej formy dokumentárneho divadla. Tým, že námet hry z devät’desiatych rokov o staršej kauze, mafiánskom zabíjaní (ktoré síce obyčajných l’udí tak netrápilo ako celkový stav zdravotníctva či začínajúca 


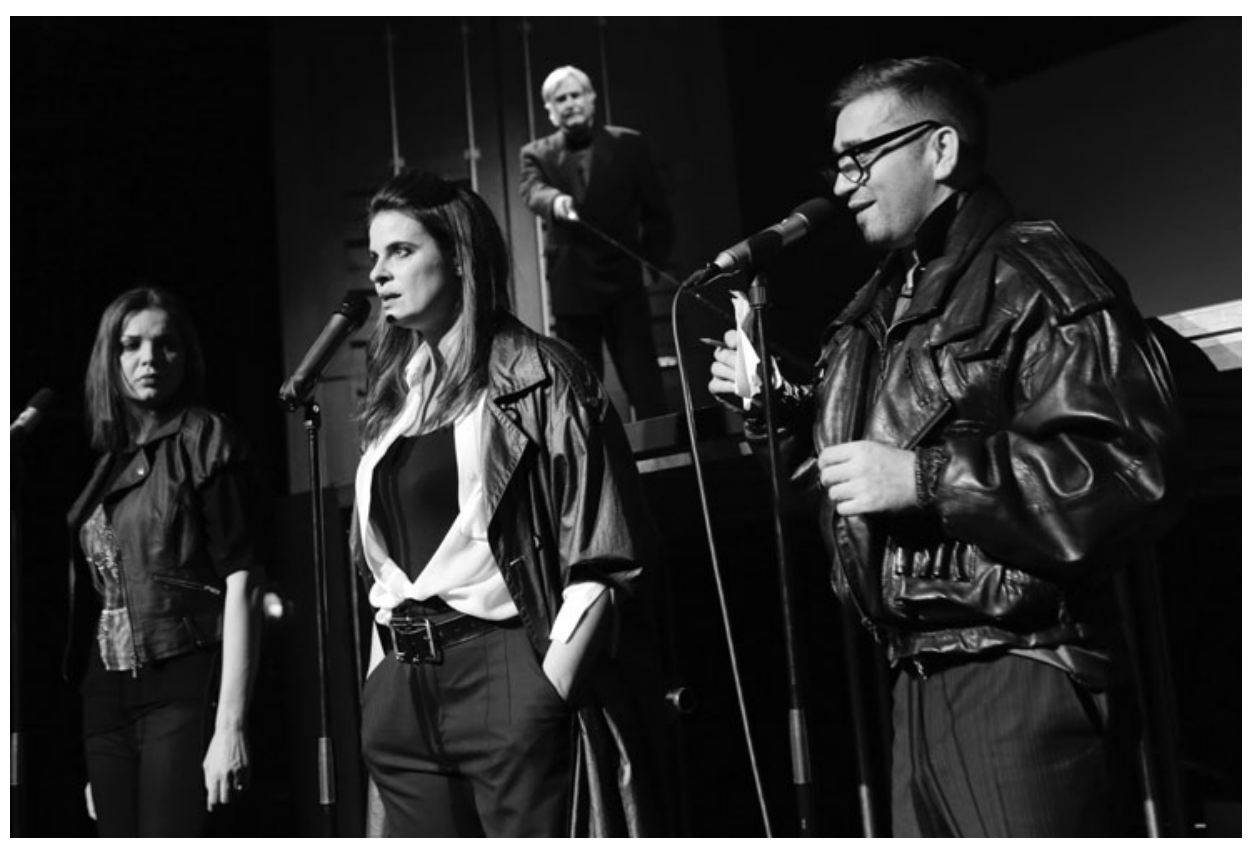

Eugen Gindl: Karpatský thriller. Činohra Slovenského národného divadla, premiéra 13. 11. 2013. Réžia Roman Polák. Zl’ava Petra Vajdová (Nad’a/Líštička), Zuzana Fialová (Zuna), Milan Ondrík (Bubo a jeho reinkarnácie), v pozadí Dušan Jamrich (Fonundcu). Foto archív SND. Snímka Ctibor Bachratý.

nedôvera v súdnictvo a i.) ${ }^{13}$ zdivadelnili a záverečnou výzvou k divákom využili Brechtov princíp epického politického divadla, vyjadrili svoj občiansky postoj. Étos inscenácie s prispôsobeným textom na tvar modlitby ocenili aj českí divadelní publicisti, ktorí sa ale, rovnako ako slovenskí kritici, zmienili aj o žánrovej nevyrovnanosti celej inscenácie. ${ }^{14}$

K obdobnej téme sa vrátili $\mathrm{v}$ činohre až o dva roky neskôr. Nie cez dokumentárnu drámu, ale dramatizáciu kultového románu Petra Pištanka Rivers of Babylon ${ }^{15}$. Pôvodné dielo (1991), ktoré doma vyšlo vo viacerých vydaniach, odhaluje drsným štavnatým jazykom perifériu podsvetia (kšeftárov, pasákov, prostitútok) na prelome osemdesiatych a devätdesiatych rokov. Slovinský režisér Diego de Brea sa pri dramatizácii zo slovinského prekladu nesústredil na tie hrozné roky devät’desiate (povedané slovami Uny z Karpatského thrillera), ale vybral si iba podstatné znaky toho obdobia, bez odbočiek na viaceré podružné postavičky a ich príbehy. V jeho divadelnom videní a spracovaní románu, ktorého dej sústredil len do kotolne hotela Ambassador, sa vytratil sarkazmus, hyperbola, groteskný i komiksový pohl’ad, zdôraznila

${ }^{13} \mathrm{O}$ zastaranosti témy pozri aj ČOBEJOVÁ, E. Politický thriller v Národnom. In .týždeň, 12. 11. 2013. [online]. [cit. 17. 4. 2020]. Dostupné na internete: https://www.tyzden.sk/nazory/22952/politicky-thriller-v-narodnom/. V tlačenom vydaní príspevok nevyšiel.

${ }^{14}$ Napr. KERBR, J. Májový divadelní slalom. In UNI: kulturní magazín, 2014, roč. 24, č. 7, s. 28, 31; tiež BEŇOVÁ, J. Mutanti spod Tatier. In kød, 2014, roč. 8, č. 1, s. 12 - 17. SND.

${ }^{15}$ Dramatizácia, réžia a scéna Diego de Brea, kostýmy Katarína Holková, premiéra 30. 1. 2016 v Štúdiu 
sa drsnost’ doby a l'udí. Činohra ponúkla paralelu so súčasnost’ou, obraz reality, ako sa od vekslovania s valutami dá dostat’ $\mathrm{k}$ moci a skončit’ v oblekoch politikov a zbohatlíkov. Od zobrazovanej doby prešlo skoro štvrt’storočie, preto inscenácia nevyvolávala pocit potreby niečo zmenit' (lebo isté zmeny sa predsa len udiali), ale emotívny divadelný zážitok.

Karpatský thriller i Rivers of Babylon cez divadelnú hyperbolu upozornili na negatívne javy spoločnosti, ktoré vychádzali z konkrétnych udalostí a predobrazov. Ukázali, ako prerástli do 21. storočia a ako sa usadili v demokratickej spoločnosti. Okrem reakcie Patrika Tkáča zo skupiny J\&T, ktorý na svojom verejnom profile na facebooku zverejnil výhrady voči záverečnej reči Zuzany Fialovej v postave (občianky) Zuny v Karpatskom thrilleri, ${ }^{16}$ sa neozval nikto z dotknutých podnikatel'ov. O tri roky neskôr pri zdanlivo nekonfliktnom projekte pre školy bolo už všetko inak.

\section{Príspevok do spoločenského diskurzu}

Pri príprave autorského divadla Natálka $(2016)^{17}$ nikto nepredpokladal, že niekto podá návrh na jeho zákaz. Inscenácia približuje skutočnú udalosť z roku 2009, ktorá sa odohrala v Českej republike, ked’ štvorica mladých neonacistov vhodila zápalné flaše cez okno do domu rómskej rodiny. Okrem materiálnych škôd a zranenia matky spôsobili dvojročnému dievčatku popáleniny na 80 \% tela. Natálka absolvovala množstvo operácií, pričom jej museli amputovat’ niekol'ko prstov na rukách. Záujem médií o následky tejto udalosti a súdny proces s obvinenými vyvolali v Čechách aj širší záujem hovorit’ o extrémizme z viacerých uhlov pohl'adu. Po nadobudnutí právoplatnosti rozsudku pre štvoricu mladých bola jednou z tém aj výška nepodmieneného trestu (dvadsat' a dvadsat'dva rokov).

Ciel'om SND bolo pripravit' 45-minútovú inscenáciu, ktorú by prednostne hrávali na školách a bola by podkladom na bezprostrednú diskusiu so študentmi o súčasných spoločenských otázkach. Režisér Matúš Bachynec a dramaturgička Miriam Kičiňová vychádzali pri scenári z podkladov dokumentačného charakteru (články, prehovory obžalovaných i matky Natálie na súde, vyjadrenia politikov, obyčajných občanov a obrazový, prevažne televízny materiál). ${ }^{18}$ Nezdôrazňujú v ňom emotívnu rovinu príbehu, sledujú fázy napadnutia až po odsúdenie mladých l'udí.

Hrá sa na malom priestore, $v$ ňom dominuje maketa dvoch stien domu z čiernych tabúl' s jedným otvorom (znak okna), na ktorú možno písat bielou kriedou. Scénu dopíňa na lavej strane televízor na stolíku, sprava taburetka a na zemi biela plyšová hračka.

16 Pozri https://www.omediach.com/tlac/item/2894-patrika-tkaca-poburila-investigativna-novinarka-fialova?fb_comment_id=700351643308724_7569823, resp. https://www.topky.sk/cl/100313/1369677/Otvoreny-konflikt-milionara-Tkaca-s-Fialovou-a-SND--Vojna-kvoli-korupcii--krvi-a-brutalite-. [cit. 17. 4. 2020].

${ }^{17}$ Inscenácia pre stredné školy Natálka vznikla v úzkej spolupráci so združením Living Memory a Bratislavským samosprávnym krajom v rámci projektu Divadlom proti extrémizmu. Scenár Matúš Bachynec, Miriam Kičiňová, réžia Matúš Bachynec, scéna a kostýmy Ján Husár. Premiéra 5. 12. 2016 v Modrom salóne SND.

${ }^{18}$ Okrem verejne dostupných reportáží tesne po udalosti a sledovania súdneho procesu, demonštrácií neonacistov z okolia Vítkovíc (kde sa skutok stal), ako aj proti nim, vznikol hodinový dokumentárny film, zachytávajúci aj psychickú traumu rodiny, osobitne dievčatka i matky, ktorým dobrovolne bez pomoci štátu pomáhali aj psychológovia. Pozri https:/www.ceskatelevize.cz/ivysilani/10302201815-35-mesicu-s-natalkou/. [cit. 17. 4. 2020]. Na filme, ktorý bol súčastou širšieho projektu Pre Natálku, sa scenáristicky podiel’al Fedor Gál. S ním konzultovali aj scenáristi SND. 


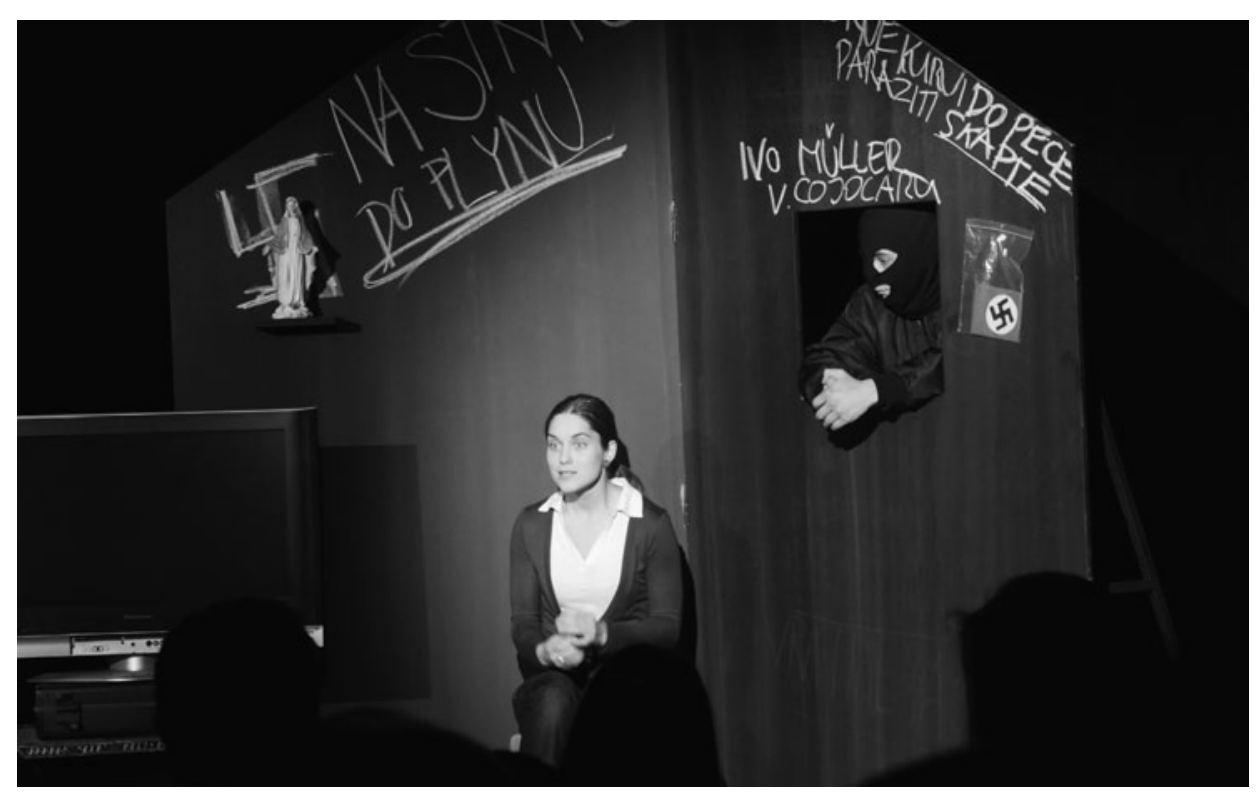

Matúš Bachynec, Miriam Kičiňová: Natálka. Činohra Slovenského národného divadla, premiéra 5. 12. 2016. Réžia Matúš Bachynec. Judit Bárdos (Anna Siváková) Foto archív SND. Snímka Alena Klenková.

Natálkina matka Anna Siváková (Judit Bárdos) hovorí oznamovacím tónom o udalosti, jej následkoch, utrpení, nedostatku financií na liečbu dcéry, najmä však o strachu, psychickom poznačení Natálky a čiastočne aj jej rodiny. Nepriamo sa prihovára štyrom útočníkom (stvárňujú ich dvaja mladí herci - Marek Koleno, Richard Autner/Igor Schlosser), ktorí striedavo zobrazujú aj prokurátora i obhajcu jedného z útočníkov.

Obsah matkiných tichých informatívnych prehovorov bez osobitného citového podfarbenia či štylizácie, ani prejavy obhajoby nepôsobia tak surovo ako úryvky z televíznych šotov a urážajúce nápisy, ktoré útočníci píšu počas predstavenia na tabul’u spolu s hákovými krížmi, kde sa napokon ocitnú aj skutočné mená odsúdených s výškou ich trestov. Najdrsnejšie vyznieva v televízii vyjadrenie bývalého najvyššie postaveného českého politika o nečakane vysokých trestoch s poznámkou, či takýto krok zabráni podobným konaniam.

Zatial' čo sa v českej spoločnosti miešali rasistické a antirasistické názory a po zverejnení sumy finančných prostriedkov zo zbierok občanov sa zmenili na závistlivé komentáre, slovenskú societu ponechal tento divadelne spracovaný príbeh spočiatku viac-menej l’ahostajnou. Na jednej z prvých diskusií študentov s tvorcami a historikom na prestížnom bratislavskom gymnáziu v roku 2017 vznikla ostrá debata aj na tému ne-existencie demokracie, nesúhlasu s rôznymi sociálnymi balíčkami pre Rómov a iných javov v spoločnosti, s ktorými nesúhlasia.

Inscenácia sa zviditel'nila až po podaní oznámenia ${ }^{19}$ na Generálnu prokuratúru Slovenskej republiky pre podozrenie $\mathrm{z}$ hanobenia rasy, národa a presvedčenia, ktoré-

${ }^{19}$ Podnet podali člen L’udovej strany Naše Slovensko Anton Čulen a Igor Cagaň. 


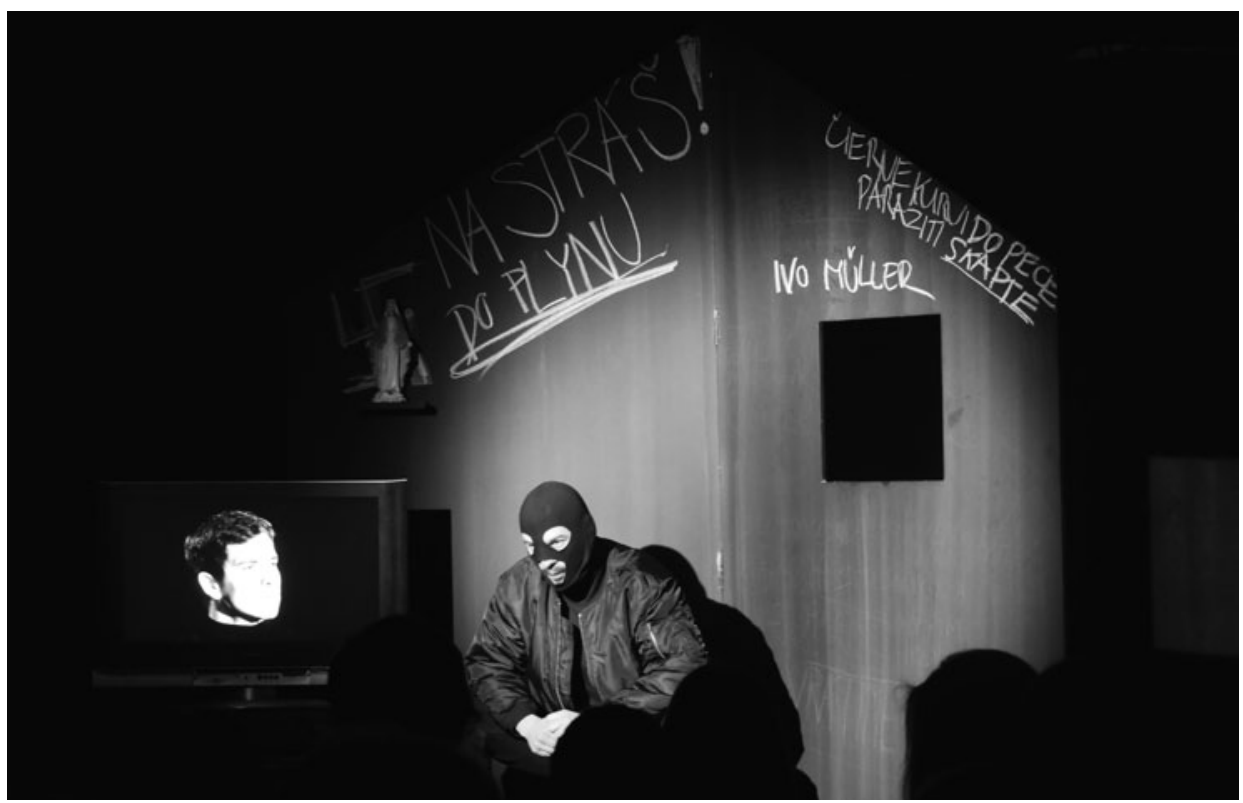

Matúš Bachynec, Miriam Kičiňová: Natálka. Činohra Slovenského národného divadla, premiéra 5. 12. 2016. Réžia Matúš Bachynec. Zl’ava Richard Autner, Marek Koleno. Foto archív SND. Snímka Alena Klenková.

ho ciel’om bol zákaz jej uvádzania. Odmietavý názor si navrhovatelia utvorili len na základe fotografie, ktorá zachytáva situáciu, ked’ matka drží v rukách sošku Panny Márie, v ktorej má odložené našetrené peniaze, a položí ju na policu pred nakreslený hákový kríž. Pritom navrhovatelia inscenáciu nevideli, vychádzali len z fotografie, ktorá v nich vyvolala pohoršenie. Podanie bolo zamietnuté ako neodôvodnené, ale útok pokračoval kyberšikanou na dramaturgičku.

V tom čase sa nezapojili do diskusie ani tí divadelníci, ktorí inscenáciu videli na pozvanie divadla. Tak by sa bola verejnost' dozvedela, že dej sa začína príchodom matky, ktorá drží sošku v rukách. Prežehná sa, pobozká Pannu Máriu a začína sa modlit’ v rómčine: „Av ašardi Maria, // o raj tuha // ašard'i sal maškaro džuvlija // a ašardo mi avel tiro čhavo o Ježiš...". [Zdravas', Mária milosti plná, // Pán s tebou. // Požehnaná si medzi ženami // a požehnaný je plod života tvojho, Ježiš...]. Počas jej modlitby dve postavy v čiernom s kuklami kreslia na stenu/tabulu svastiku, pozdrav „NA STRÁŠs", „ČIERNE KURVI DO PECE“, „DO PLYNU“, „PARAZITI SKAPTE!“ Matka odloží sošku na policu, za ktorou je nakreslený hákový kríž. Paralelne beží v televízii krátky šot z demonštrácie nacistov. ${ }^{20}$ Matka kresby „nevidí“, lebo nie sú na vnútorných stenách izby ich domčeka, sú však všelikde inde po múroch. ${ }^{21}$ Skutočnost', že sa porcelánová soška - symbol materstva a matky Anny Sivákovej, ktorá

${ }^{20}$ Záznam inscenácie je dostupný na stránke jedného bratislavského gymnázia spolu s privítaním a celou diskusiou s hostami. Pozri https://bilgym.sk/s-natalkou-a-divadlom-snd-spolu-proti-extremizmu/. [cit. 6. 5. 2020].

${ }^{21}$ Ide o umelecké pretlmočenie postoja niektorých sympatizantov neonacistov k rómskym spoluobčanom. 


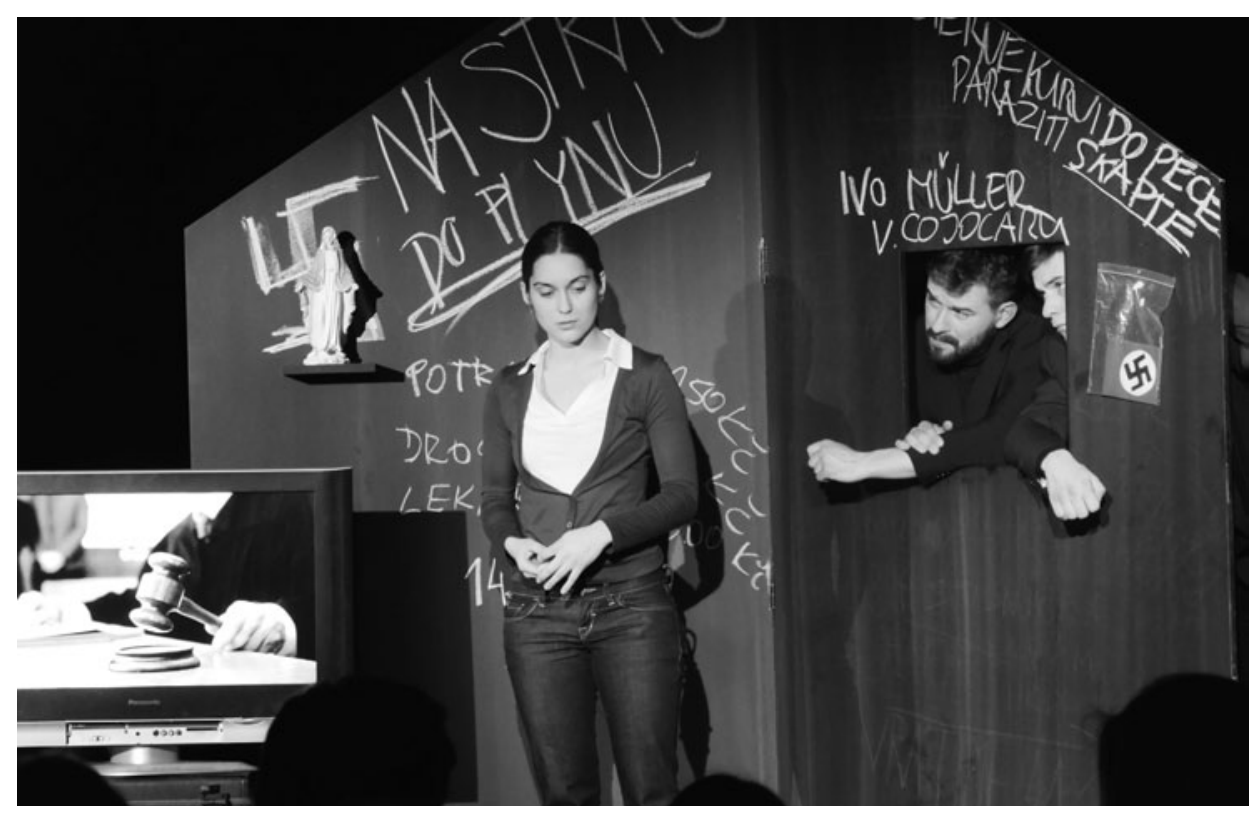

Matúš Bachynec, Miriam Kičiňová: Natálka. Činohra Slovenského národného divadla, premiéra 5. 12. 2016. Réžia Matúš Bachynec. V popredí Judit Bárdos (Anna Siváková), Richard Autner, Marek Koleno. Foto archív SND. Snímka Alena Klenková.

by rada zobrala trápenie svojej dcéry na seba tak ako Panna Mária - ocitá pred symbolom nacizmu, je umelecká skratka informácie z exteriéru prenesená do interiéru.

Predstavenie má dve roviny: divadelnú (emotívnu) a dokumentárnu. Divadelnost' tu ustupuje $\mathrm{v}$ prospech opisu toho, ako sa mladí neonacisti kontaktovali, pripravili na čin, ako ho urobili. Ani po vynesení rozsudku svoj skutok neol’utovali, ich priatelia aj po roku pripravovali pochod za ich oslobodenie, obviňujúc rodinu Sivákovú. Tieto informácie a televízne zábery na popálenú Natálku sú ovel’a silnejšie ako nápisy na tabuli, vrátane posledného „VRÁTIME SA!“. Divadelná výpoved” má univerzálne posolstvo bez ohladu na farbu pleti.

Záujem verejnosti i publicistiky o Natálku sa presunul od hodnotenia umeleckej kvality do mimoumeleckej sféry. Ohlasy na facebooku či rôznych weboch vyčítali inscenácii zneužitie viery v Boha cez spojenie sošky s hákovým krížom, kukly na hlavách mladých a i. Tvorcovia hrali v rôznych mestách po Slovensku, súčastou každého predstavenia bola diskusia so študentmi. Na väčšine z nich sa zúčastnili historici L'ubomír Morbacher a Martin Slávik. SND divadelným projektom sociálneho divadla zameraného proti extrémizmu oficiálne prekročilo pomyselnú hranicu medzi javiskom a hladiskom. Študenti sústredene sledovali predstavenie, ktoré na konkrétnom prípade otváralo otázku spolužitia, nenávisti, násilia a ich dôsledky. Lebo Natálka je celoživotne postihnutá nielen fyzicky, ale aj psychicky, s následkami traumy sa bude vyrovnávat po celý život. ${ }^{22}$

${ }^{22}$ Vel’mi zaujímavo o tejto téme hovoria dvaja psychológovia. Redakcia publicistickej relácie nahrávala 
Na (zatial') poslednom predstavení v septembri 2019 v Bratislave v Divadle Aréna, napriek nevhodnosti priestoru (vel'ký odstup medzi tvorcami a divákmi), boli študenti petržalských škôl tiež pozorní. Ale následná riadená diskusia od stola na javisku v réžii usporiadatela Bratislavského samosprávneho kraja ${ }^{23}$, bez účasti historika, sociológa či psychológa, nevyvolala u študentov skoro žiadnu odozvu. Napriek tomu, že mladí ludia sa mohli anonymne špeciálnou aplikáciou cez smartfón a internet pýtał či vyslovit’ svoj názor. Zaujala otázka, prečo sú zakázané tie (fašistické) symboly, na ktorú sediaci za stolom nevedeli odpovedat’ s ospravedlnením sa, že nie sú historici. Hostia hovorili viac o sebe, nevedeli podnietit diskusiu, akoby ich názor mladých nezaujímal. Ak by bol niekto položil otázku o význame pravopisných chýb v slovách na tabuli (o čom si chlapci v hladisku len šepkali), mohlo sa hovorit’ aj o priamej súvislosti divadla (využitie metafory) a sympatizantov odkazu nacizmu (ich gramotnost'). Organizátori vyčlenili najviac času pre vystúpenie speváčky Celeste Buckingham. Takáto „diskusia“ upozornila na problém prípadnej diskrepancie medzi záujmom a ciel’om divadla a spoluorganizátorov, ktorá sa môže preukázat’ pasivitou diváka/občana aktívne sa zapájat’ do vecí verejných.

\section{Politika v divadle}

Politicky najsilnejšie vyznela v Činohre SND inscenácia Sofoklovej Antigony v roku 2018. ${ }^{24}$ Premiéra sa uskutočnila v čase, ked' čast’ spoločnosti už dlhšie vyjadrovala nespokojnost’ s korupciou aj na ústredných orgánoch štátnej správy, s nízkou vymožitel'nostou práva, podozrením na prepojenie niektorých predstavitel’ov bezpečnostných zložiek s organizovaným zločinom a i. Antigona je hra nielen o neposlušnej rebelke, ale aj o vládcovi, ktorý koná podla svojich zákonov a každé spriečenie sa, aj tých najbližších, trestá. Divadelníci neraz zaradia tento text o konflikte lásky a moci do dramaturgického plánu s cielom vyjadrit’ nesúhlasný postoj s politickým smerovaním krajiny. Spravidla tak, že ich výpoved’ má univerzálnu, nadčasovú hodnotu, a predsa sa dotýka diania v konkrétnej zemi.

Inscenačný tím činohry predlohu citlivo skrátil najmä vo vnútri prehovorov, čo neublížilo základnému príbehu. Výklad situácií, stretu názorov a logických zdôvodnení rozhodnutia oboch strán v súčasných kostýmoch a scénografii bol jasne čitatel’ný. Režisér Ondrej Spišák premiestnil dej z námestia spred královského paláca v Tébach do univerzálneho priestoru auly či parlamentu s amfiteatrálnym sedením. Veršované rozprávanie rozšíril o autorské songy speváčky Kataríny Kubošiovej, ktorej umelecké meno Katarzia tu nemá rovnaký účinok ako v antickej dráme. Je tichým, ale dôležitým hlasom mladej generácie, nespokojnej so status quo, vytvára akési alter ego hlavnej hrdinky a, ako sa neskôr ukáže, aj spoločnosti. Kubošiovej piesne odrážajú jej pocity a myslenie. Skôr než sa dostanú k slovu Antigona (Monika Potokárová)

v rodine a potom v pohostinskom zariadení. Pozri https://www.tyzden.sk/podlampou/31588/pod-lampou-dievca-ktore-chceli-nackovia-zabit/, ako aj https:/www.youtube.com/watch?v=VjoqjJtbe-A. [cit. 6. 5. 2020].

${ }^{23}$ Bratislavský samosprávny kraj sa v roku 2017 sa po útokoch na tvorcov postavil na stranu inscenátorov, čo tiež vyvolalo nepríjemnú protireakciu. Pravdepodobne tentoraz usúdili, že v divadelnom priestore Arény treba študentov aj zabavit’.

${ }^{24}$ Preklad Lubomír Feldek, úprava Darina Abrahámová a Ondrej Spišák, scéna František Lipták, kostýmy Katarína Hollá, hudba Katarzia, Pjoni (Jonatan Pastirčák), texty piesní Katarzia (Katarína Kubošiová). Premiéra 14. 4. 2018. 


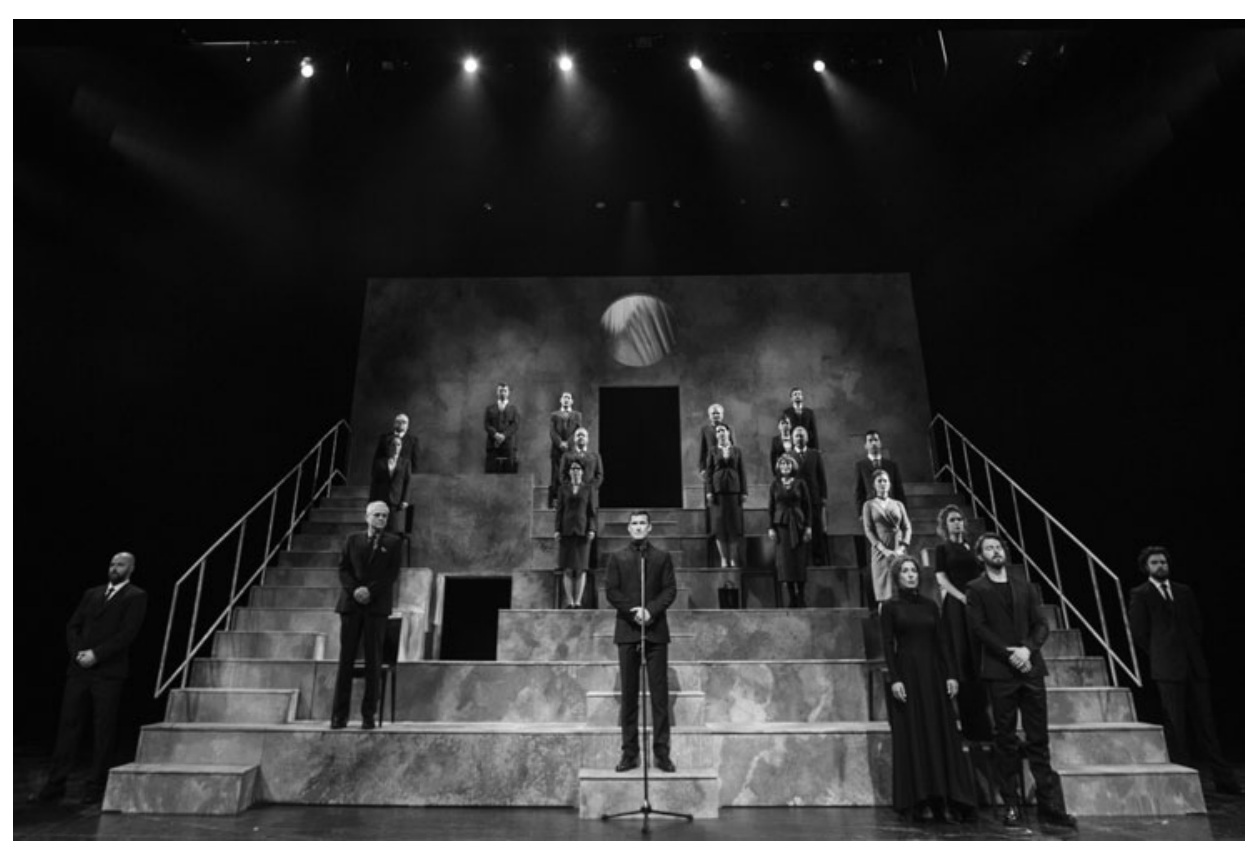

Sofokles: Antigona. Činohra Slovenského národného divadla, premiéra 14. 4. 2018. Réžia Ondrej Spišák. V strede Ján Koleník (Kreón), za ním zbor, napravo v popredí Ganrila Dzúriková (Eurydika, jeho žena), Richard Autner (Haimón, jeho syn), tesne za nimi Dominika Kavaschová (Isména). Foto archív SND. Snímka Ctibor Bachratý.

a jej sestra Isména (Dominika Kavaschová), Katarzia vstupuje do deja úvodnou piesňou, vyjadrujúcou Antigonin, ale najmä svoj generačný nesúhlas s tým, čo sa odohráva okolo: „Myslíš, že nemôžeme nič zmenit? (...) pretože sme iba ženy?“ a pokračuje: „Otravujú ma vaše obavy // Otravuje ma // Ako si tu každý snaží niečo vybavite.“25 V d’alšom vstupe pritvrdzuje, ked’ spieva: „Chcú, aby som mlčala // ale ja neustúpim // chcú aby som ústa držala // nikto ma nedonúti..." ${ }^{\text {26 }}$ Tým zvestúva postoj tvorcov.

Po úvodnom dialógu oboch sestier, v ktorom sa Antigona telefonicky cez mobil priznáva Isméne, že sa napriek Kreónovmu zákazu rozhodla tajne pochovat ich brata Polyneika, režisér nasvieti auditórium zboru. Jeho náčelník (Stefan Bučko) schádza bez ovácií po schodoch zvrchu dolu k svojmu ludu, rozdeleného na rovnaký počet po oboch stranách. Spolu pripomenú spor bratov o trón, pri ktorom obaja zahynuli.

Rovnako zvrchu prichádza vyšportovaný, sebavedomý a elegantný vládca Kreón (Ján Koleník), rád prijímajúci podporu vybraných zástupcov l’udu. Obratný v jazyku, s múdrostou štátnika verejne oznamuje svoje rozhodnutie o osude mŕtvych Oidipových synov: jedného pochovat’ s poctami, druhého ponechat psom a dravým vtákom. V̌̌etci sú v súčasných kostýmoch, aj ochranka, ktorá ručne „pripomenie“ Strážcovi (Ondrej Koval'), že vinníka, čo už raz pochoval Polyneika, musí nájst'.

\footnotetext{
${ }^{25}$ Sofokles: Antigona [Bulletin k inscenácii]. Bratislava : Slovenské národné divadlo, 2018, s. 36.

${ }^{26}$ Tamže, s. 38.
} 


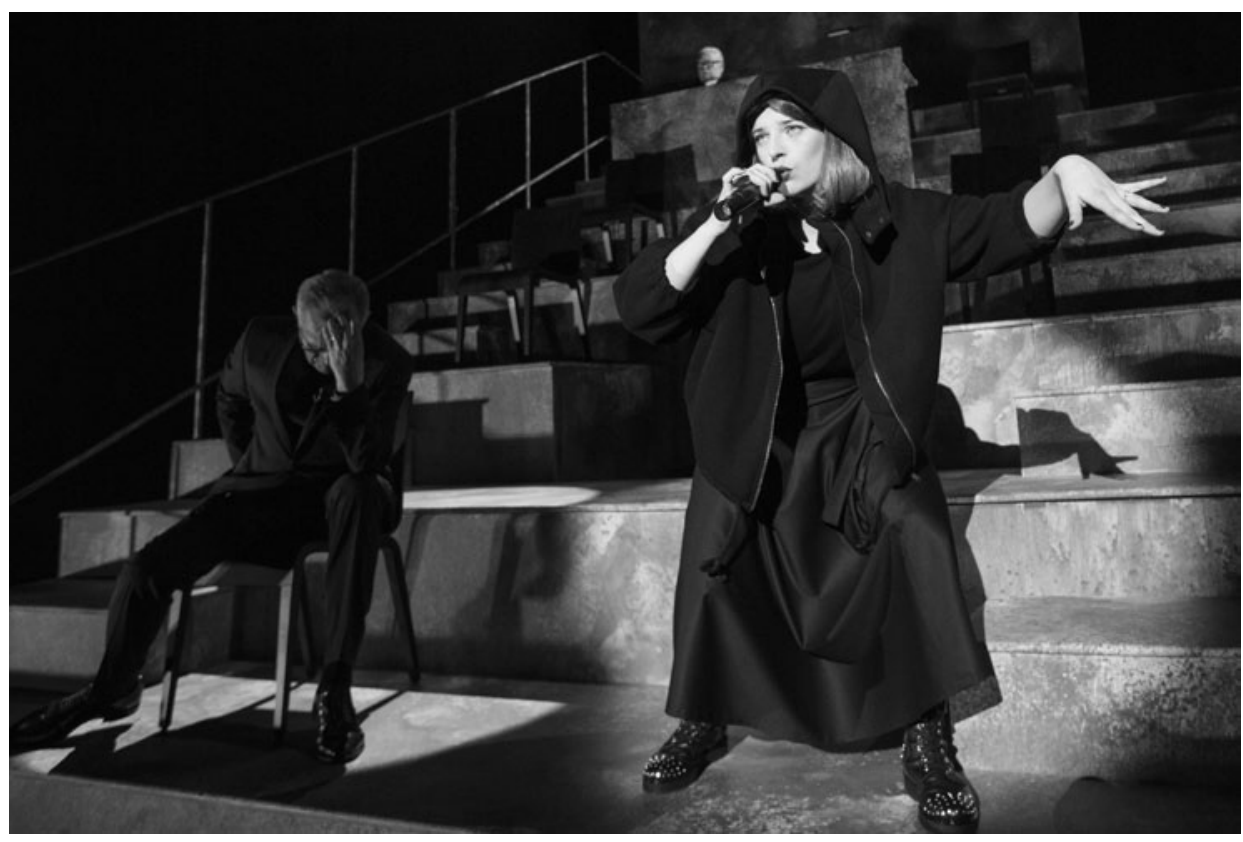

Sofokles: Antigona. Činohra Slovenského národného divadla, premiéra 14. 4. 2018. Réžia Ondrej Spišák. Katarína Kubošiová - Katarzia, vl'avo Štefan Bučko (Náčelník zboru). Foto archív SND. Snímka Ctibor Bachratý.

Po prichytení Antigony pri opätovnom pochovávaní brata, jej priznaní sa a po odchode so sestrou do hrobky vchodom z auditória, kde zasadá l’ud, sa dostávajú k slovu jeho zástupcovia. Verše ich „druhej piesne zboru“, ako ju označil Sofokles, tvorcovia rozčlenili do prehovorov viacerých z nich. Tak sa ich názory, vyčlenené z anonymnej masy, pritakávajúce vládcovi Kreónovi, zosobňujú.

Zaujímavé je sledovat jemné dramaturgické zásahy zaktuálnenia Sofoklovej predlohy skrátením dlhších monológov vo vztahu k meniacemu sa názoru Kreónovho zboru, ktorý viac než antických občanov pripomína unudených a súhlasiacich poslancov v laviciach na strmých stupienkoch k vysnívanému Olympu. Kreón v úvodných slovách priznáva ich jednofarebnost', ked’ hovorí: „Vybral som si vás a poslal po vás poslov, lebo viem, že vždy ste mali v úcte trón, či na ňom sedel už Laios, či Oidipus..." ${ }^{27}$ Ako sa neskôr ukáže, niektorí vedia výborne rečnit', iní zase zákulisne konat', spočiatku nevyjadria nesúhlas s Kreónom pochovat’ Antigonu za živa v hrobke, názor zmenia až po veštbe Teiresias. Obsadenie mužskej postavy ženskou interpretkou (Božidara Turzonovová) túto postavu zl'udštilo a u mnohých divákov mohlo vyvolat' analógiu so slepou bulharskou vešticou Babou Vangou.

Režisér Ondrej Spišák pred auditóriom s vysokými stupňami nasvecuje kruh, na ktorom sa odohrávajú všetky dôležité výstupy, podl'a ich obsahu a charakteru mení aj jeho farbu (modrá, žltá, žltooranžová, okrová s prevládajúcou červenou krvi...). Na

${ }^{27}$ Sofokles: Antigona [Bulletin k inscenácii], s. 109. 


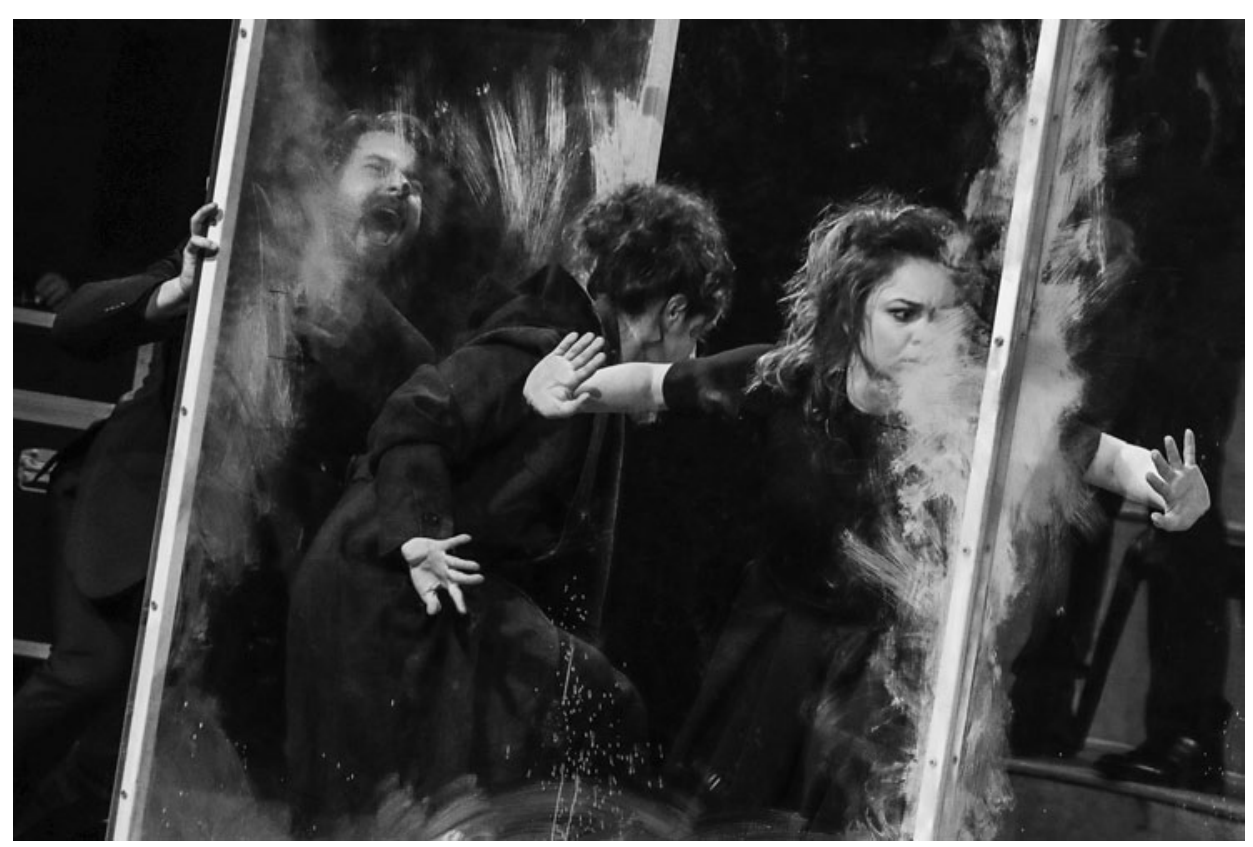

Sofokles: Antigona. Činohra Slovenského národného divadla, premiéra 14. 4. 2018. Réžia Ondrej Spišák. Zlava Richard Autner (Haimón), Monika Potokárová (Antigona), Dominika Kavaschová (Isména). Foto archív SND. Snímka Ctibor Bachratý.

tomto pomyselnom kolbisku zažíva Kreón prvý nesúhlasný stret so synom Haimónom (Richard Autner), ktorý mu najprv dáva za pravdu v jeho neoblomnosti, no napokon s ním nesúhlasí a dobrovol’ne od neho odchádza. Tu oznamuje svoju veštbu aj Teiresias. Vládca však pri rozhodovaní o odpustení vyjde z kruhu, čím priznáva svoje možné pochybenie pri trvaní na treste. Sem privezú na kolieskach presklenú hrobu s oboma zavretými sestrami, aby z nej Isména po Kreónovom omilostení priam zbabelo utiekla preč. Tu vraví už „slobodná“ Antigona posledné verše pred odchodom na smrt. ${ }^{28}$

Speváčka Katarzia využíva celý priestor pred auditóriom i po bokoch vel’kého javiska, kde je na lavej strane umiestnený aj jej hudobný partner Pjoni (Jonatan Pastirčák), ale sem-tam sa zatúla do kruhu, aby jej slová (napr. „,chcú, aby som ústa držala“) vyzneli ešte naliehavejšie. Ona je tou burcujúcou, už vyzretou rebelkou, nie Antigona Moniky Potokárovej, ktorá popri nej akoby zostala v pozadí, krehká a odhodlaná, ale poddimenzovaná so svojou vzburou. Cez piesne Katarzie tlmočí režisér posolstvo inscenácie hovorit’ o dnešku slovami generácie $Y$, ako na to upozornil kritik Milo Juráni. ${ }^{29}$

V takejto interpretácii antiky prechádza najvýraznejšou premenou vládca Kreón v zobrazení Jánom Koleníkom. Od sebaistoty, pripomínajúc gestá jedného z domácich politikov, vrátane naznačenia cvičenia, ktorým sa nemenovaný politik

${ }^{28}$ Pri čítaní textu v bulletine aj spätne mrazí, najmä v súvislosti so samovraždou herečky v novembri 2019. M. Potokárová prednášala verše pokorne, plne uzrozumená so svojím osudom.

${ }^{29}$ JURÁNI, Milo. Čo (sa) patrí divadlu a čo realite. In .týždeň, 2018, roč. 15, č. 17, s. 48. 


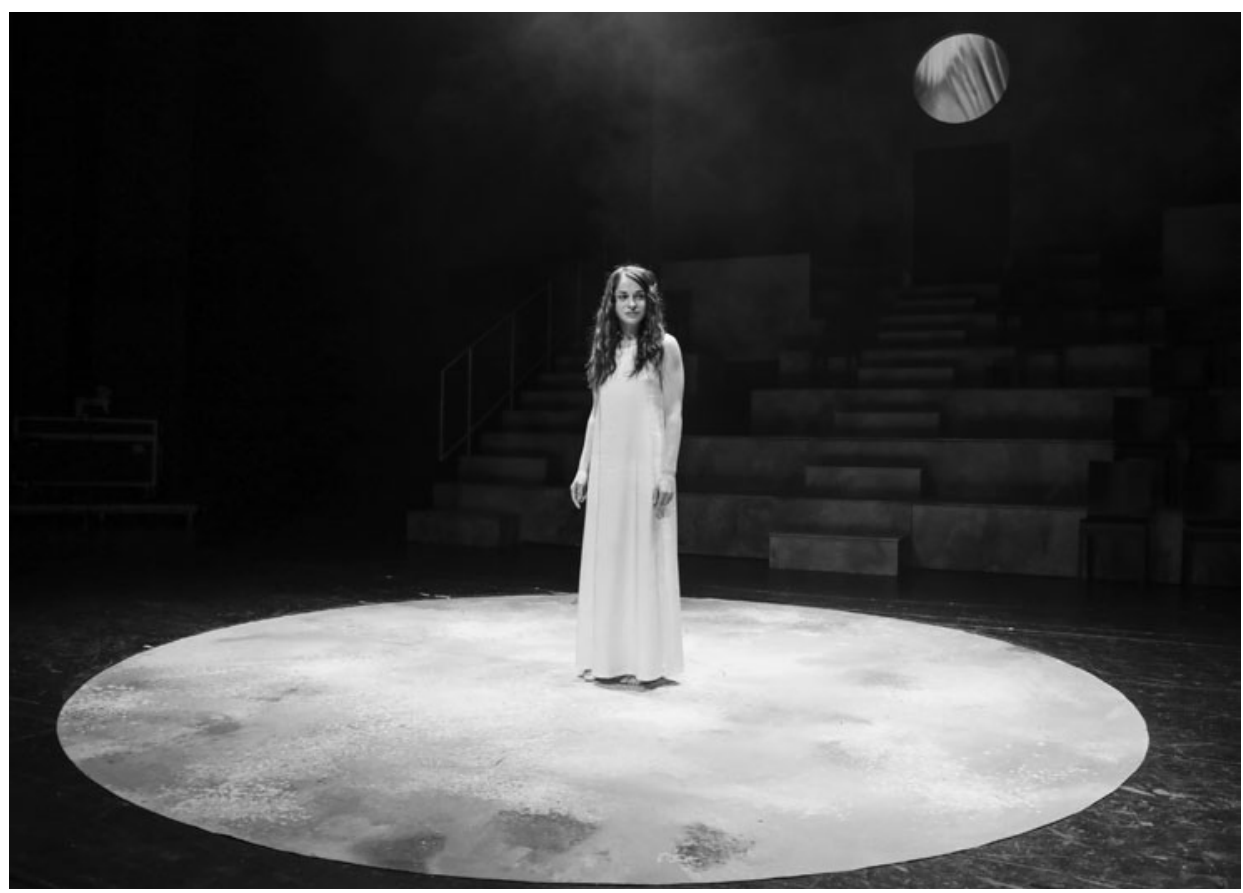

Sofokles: Antigona. Činohra Slovenského národného divadla, premiéra 14. 4. 2018. Réžia Ondrej Spišák. Monika Potokárová (Antigona) pri záverečnom monológu. Foto archív SND. Snímka Ctibor Bachratý.

často prezentoval, k schopnosti ovládat' l'udí, udržat' poriadok, herec predstavuje miestami sympatického človeka, ktorý neodhadne správnu chvílu na zmenu (u autora rozhodnutie o potrestaní Antigony) a čaká ho pád.

Antigona so svojím snúbencom zomierajú inou smrtou než u Sofokla: $\mathrm{z}$ hrobky počut tri výstrely po tom, ako tam vojdú dvaja muži v čiernom, ktorí bez toho, aby ich niekto zastavil, odtial' aj vyjdú. Zvest’ o smrti Haimóna i Antigony prídu jednotlivo oznámit’ až dvaja poslovia. Bývalý Strážca, teraz už nie v maskáčoch, lež v obleku, zdôrazňuje, že Kreónova neter sa sama uškrtila závojom. Po smrti snúbencov sa divadelná inscenácia s množstvom jemných i kričiacich metafor zmení na politickú manifestáciu. Tí, čo doteraz posluhovali vládcovi, prinesú vel'kú čiernobielu fotografiu Haimóna a Antigony, ktorá vel'kostou a aranžmánom kopíruje známy portrét Jána Kuciaka a jeho snúbenice Martiny Kušnírovej, ktorí boli zavraždení koncom februára 2018. Po niekol'kých mesiacoch fotografiu ukážu divákom len na okamih a hned' obrátia tak, ako sa odkladá zvesený obraz. Neskôr už fotografiu nepoužili. Na sile výpovede to neubralo, lebo metafora antického príbehu a dneška funguje aj bez obrazu mladej dvojice.

Politické divadlo, ak sa oň tvorcovia usilovali prostredníctvom Antigony, nepotrebuje násilné zaktualizovanie na hrane politizácie. Potvrdzuje to aj záver inscenácie. Dobrovol'nú smrt’ Kreónovej manželky Eurydiky (Gabriela Dzuríková) oznamuje siréna úrazovky, až potom prichádza zástupkyňa l’udu (Zuzana Kocúriková) zvestovat’ d’alšie neštastie. Z Kreóna sa stáva troska, priznáva svoju prehru: „Som nič. Som 


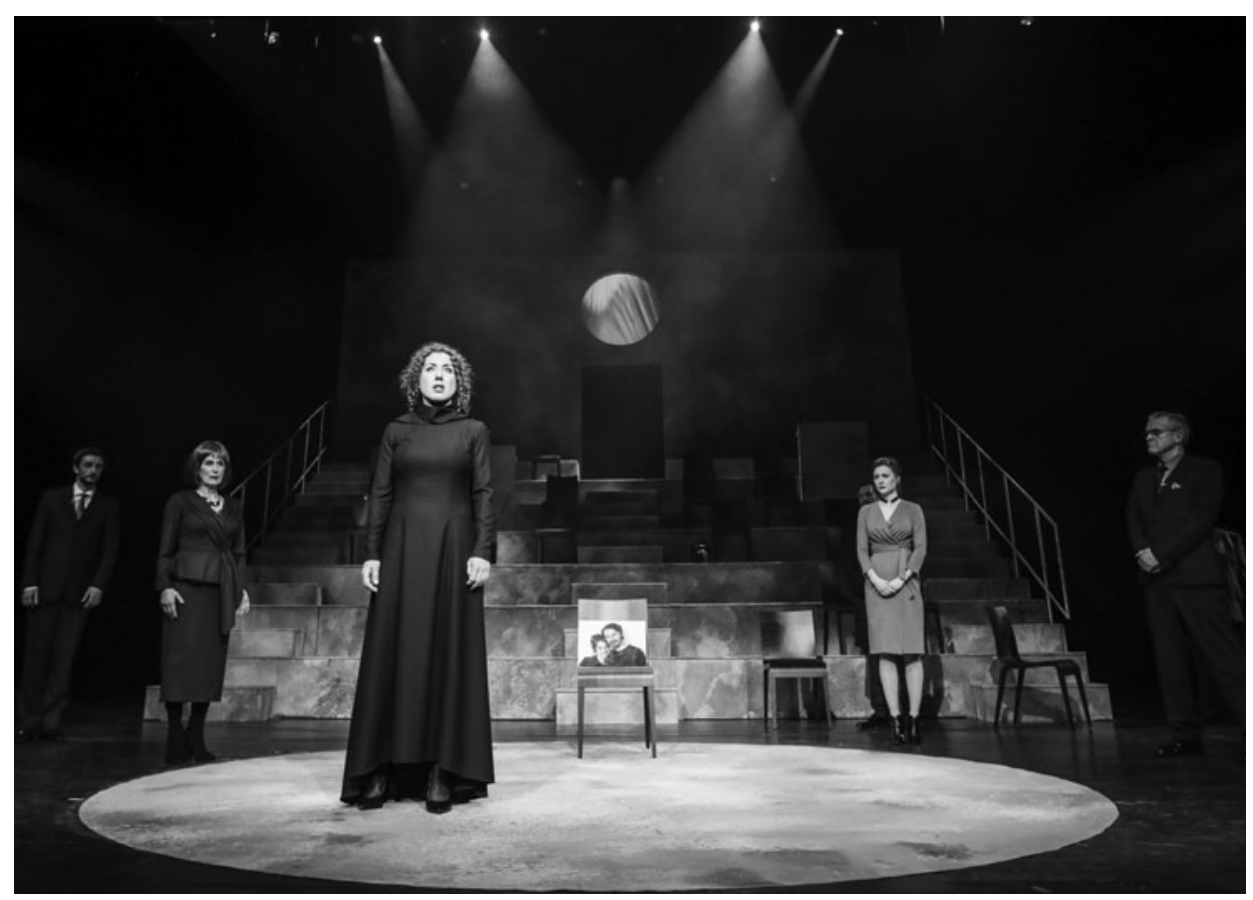

Sofokles: Antigona. Činohra Slovenského národného divadla, premiéra 14. 4. 2018. Réžia Ondrej Spišák. V strede Gabriela Dzúriková (Eurydika, Kreónova manželka) s fotografiou mútvych detí: Monika Potokárová (Antigona), Richard Autner (Haimón). Foto archív SND. Snímka Ctibor Bachratý.

hrozné nič, čo seba nemá“30 znejú jeho posledné slová. Opúšta ho aj „jeho“ l’ud. Prichádza malé dievčatko, ktoré sprevádzalo predtým Teiresias, tentoraz už ona tlmočí odvekú pravdu o tom, že človek, ktorého drží „vlastná pýcha v područí, // vel'kému trestu neunikne // a konat’ s rozvahou // až na staré kolená sa naučí. " 31 Dvakrát prejde po okraji kruhu, a tak pomyselne uzatvára príbeh úvodnej piesne Katarzie, že aj ženy môžu niečo (v modernej spoločnosti) zmenit. Režisér túto chvílu znásobuje otočením auditória a zlomený Kreón sa ocitá v hrobke, do ktorej cez vchod (z opačnej strany auditória) preniká mesačný svit.

\section{Záver}

Činohra Slovenského národného divadla plánuje ponechat’ inscenáciu Antigony v repertoári aj v sezóne 2020/2021. Bude zaujímavé sledovat', ako zarezonuje u divákov viditelná súvislost’ medzi násilnou smrtou snúbencov roku 2018 a postupnými zmenami v slovenskej spoločnosti, ktoré sa pomaly začínajú diat'.

Posledných tridsat' rokov nemáme v slovenskom divadle vel'ké skúsenosti s takým angažovaným divadlom, ktoré by umne prepájalo umenie a politiku. Nemusí íst’ o nastolenie politických problémov na javisku a pokus o ich riešenie (napríklad na

\footnotetext{
${ }^{30}$ Sofokles: Antigona [Bulletin k inscenácii], s. 129.

${ }^{31}$ Tamže.
} 
tému neonacistických strán ako v berlínskom Divadle Maxima Gorkého), či o spätný pohl'ad na revolučné udalosti, ktoré zmenili politické smerovanie krajiny (ako príklad možno uviest' inscenáciu Desat’ dní, ktoré otriasli svetom v Moskovskom divadle drámy a komédie na Taganke pred vyše polstoročím) a mnohé iné projekty zo zahraničných scén minulosti i dneška. Politika za každého režimu prenikala na javiská, ktoré mu neraz aj slúžili, preto je medzi ňou a umením vel’mi tenká čiara. Závisí od tvorcov, ktorým smerom sa poberú a či majú ciel’ robit’ politické divadlo. Tento pojem už od čias Erwina Piscatora vyvoláva v Európe diskusiu samotným označením. Súčastou umenia by mal byt’ verejný diskurz o poslaní súčasného divadla, ktoré by malo okrem ponuky umeleckého zážitku rozvíjat’ u diváka potrebu zamýšl'at’ sa nad aktuálnymi spoločensko-politickými problémami v jeho krajine, respektíve aj v širšom kontexte. Do istej miery splnili tento ciel’ projekty dramaturgickej línie „Endlösung“ v SND a Divadle Aréna.

Ciel'om tejto štúdie nie je zamyslenie sa nad súčasným politickým divadlom, ale priblíženie vzorky inscenácií činohry našej prvej scény, pri ktorých možno pomenovat' prestupovanie politiky a divadla. Pri Karpatskom thrilleri toto spojenie neoslovilo verejnost' natol'ko, aby o nastolených témach diskutovala. Pri Natálke nastal opačný extrém, ked’ inscenácia určená predovšetkým študujúcej mládeži vyvolala diskusiu, ktorá smerovala mimo divadla. Zatial' najviac zarezonovala Antigona, ktorá však upozornila na možný odklon od politického divadla k divadlu politizujúcemu, ked' otvorila otázku prepojenia občianskych prejavov a divadla (totožný obraz snúbencov z bratislavského námestia na javisku SND). ${ }^{32}$

Najbližšie roky ukážu, či sa pri spoločenských zmenách na Slovensku a ekonomickej kríze, ktorá ovplyvní aj financovanie divadiel, tvorcovia navrátia k divadelnému zovšeobecneniu stále platných tém, či pôjdu cestou striktnejšieho dokumentárneho divadla, alebo sa postavia zoči-voči takým spoločenským problémom, ktoré majú vplyv na celú demokratickú spoločnost'. Isté je len jedno: na strane hl'adiska nastupuje nová generácia divákov, ktorá sa chce, hoci aj nepriamo, zúčastňovat na témach, ktoré im divadlo zdiel'a.

\section{THE TRANSGRESSION BETWEEN THEATRE AND POLITICS. Using the Examples of the Theatrical Productions \\ by the Slovak National Theatre Between 2013 and 2018}

\section{Dagmar PODMAKOVÁ}

The authoress deals with the selected productions of the Drama Company of The Slovak National Theatre focusing on the portrayal of modern society. The viewer's evolution is brought to the fore, as the spectator no longer passively absorbs the theatrical form, but rather expects creators to demonstrate their political attitude through their artistic creation. To get this accomplished, theatre professionals are

\footnotetext{
32 Činohra SND uviedla aj iné inscenácie, približujúce rôzne udalosti z totalitného režimu, ktoré mali vplyv na život občanov v Československu a do ktorých logicky prestupovala politika. Z projektov, ktoré vznikli pre komunikatívnejší priestor Modrého salóna, to boli napr. Matúš Bachynec: Kabaret alebo Modlitba pre Martu, 2017 alebo L'ubomír Feldek: Nepolepšený svätec, 2017, na vel'kej scéne Jiří Havelka a kol.: Elity, 2017.
} 
free to work with more or less known older dramatic texts or with contemporary plays that utilise current body of facts and put their own knowledge to use, with Karpatsky thriller/The Carpathian Thriller (2013) being a good example. Equally, they are free to develop their own interactive authorial projects which are based on documentary material, however, in addition to sharing general information, their goal is to obtain feedback from the recipient, i.e. the viewer. Natálka/Nathalie (2016) is exactly such kind of production. It was not only a test of the theatre makers on how this sensitive topic ought to be captured, but it also was a test of the society's capacity to understand the metaphor without attempting to find an enemy in it at all costs. The most proven type of model for the application of politics in theatre is ancient drama. A well-balanced abridgment of Sophocles' Antigonal Antigone (2018) and the engagement of contemporary original music of the young generation and theatrical images are the most recent example of a political attitude of theatre makers.

Príspevok je súčastou riešenia projektu APVV č. 15-0764 Slovenské divadlo a súčasná európska divadelná kultúra - kontinuita a diskontinuita.

\section{LITERATÚRA}

BEŇOVÁ, Juliana. Mutanti spod Tatier. In kød, 2014, roč. 8, č. 1, s. 12 - 17. ISSN 1337-1800.

BLAHO, Vladimír. Ako je s naším divadlom? K výskumu vztahu slovenskej populácie k divadlu. In Slovenské divadlo, 2004, roč. 52, č. 4, s. 313 - 332. ISSN 0037-699X.

ČOBEJOVÁ, Eva. Politický thriller v Národnom. In .týždeň, 12. 11. 2013. [online]. Dostupné na internete: https://www.tyzden.sk/nazory/22952/politicky-thriller-v-narodnom/.

Eugen Gindl: Karpatský thriller [Bulletin k inscenácii]. Bratislava : Slovenské národné divadlo, 2013, 20 [novinových] s.

GINDL, Eugen - PORUBJAK, Martin. Sme všetci len herci? In Eugen Gindl: Karpatský thriller. [Bulletin k inscenácii]. Slovenské národné divadlo, 2013.10 s.

https://www.omediach.com/tlac/item/2894-patrika-tkaca-poburila-investigativna-novinarka-fialova?fb_comment_id=700351643308724_7569823

https://www.topky.sk/cl/100313/1369677/Otvoreny-konflikt-milionara-Tkaca-s-Fialovou-a-SND--Vojna-kvoli-korupcii--krvi-a-brutalite-

https://www.ceskatelevize.cz/ivysilani/10302201815-35-mesicu-s-natalkou/

https://bilgym.sk/s-natalkou-a-divadlom-snd-spolu-proti-extremizmu/

https://www.tyzden.sk/podlampou/31588/pod-lampou-dievca-ktore-chceli-nackovia-zabit/ https://www.youtube.com/watch?v=VjoqjJtbe-A

JURÁNI, Milo. Čo (sa) patrí divadlu a čo nie. In .týždeň, 2018, roč. 15, č. 17, s. 48. ISSN 1336-5932.

KERBR, Jan. Májový divadelní slalom. In UNI: kulturní magazín, 2014, roč. 24, č. 7, s. 28, 31. ISSN 1214-4169.

Kontinuálny sociologický výskum spotreby kultúry v Slovenskej republike. [online]. Dostupné na internete: https://www.nocka.sk/wp-content/uploads/2018/03/zaverecna-sprava-z-vyskumu-spotreby-kultury-2016_final.pdf.

Peter Pištánek: Rivers of Babylon [Bulletin k inscenácii]. Bratislava : Slovenské národné divadlo, $2016.91 \mathrm{~s}$

RANCIÈRE, Jacques. Emancipovaný divák. Prel. Mária Ferenčuhová. Bratislava : Divadelný ústav, 2015. 127 s. ISBN 978-80-89369-89-8.

RE: Publikum. Př́ležitosti a rizika práce s publikem. Praha : Institut umění, 2016. 55 s. ISBN 978- 
80-7008-376-5. Dostupné na internete: https://www.kreativnievropa.cz/wp-content/uploads/2018/02/2-republikum-2016_publikace_190x230.pdf. ISBN online vydania 978-80-7008377-2.

Sofokles: Antigona [Bulletin k inscenácii]. Bratislava : Slovenské národné divadlo, 2018. $136 \mathrm{~s}$.

Dagmar Podmaková

Ústav divadelnej a filmovej vedy CVU SAV

Dúbravská cesta 9

84104 Bratislava

e-mail: dagmar.podmakova@savba.sk 